\title{
Effectiveness of Banks after M \& A
}

\author{
Brajesh Kumar Tiwari \\ Department of Management Studies, Rajendra Prasad College of Management, Azamgarh, India. \\ Email: julybrajesh@yahoo.co.in
}

Received November $5^{\text {th }}, 2013$; revised December $5^{\text {th }}, 2013$; accepted December $12^{\text {th }}, 2013$

Copyright (C 2014 Brajesh Kumar Tiwari. This is an open access article distributed under the Creative Commons Attribution License, which permits unrestricted use, distribution, and reproduction in any medium, provided the original work is properly cited. In accordance of the Creative Commons Attribution License all Copyrights (c) 2014 are reserved for SCIRP and the owner of the intellectual property Brajesh Kumar Tiwari. All Copyright (C) 2014 are guarded by law and by SCIRP as a guardian.

\section{ABSTRACT}

The goal of a bank merger is to increase the bank's value in one way or another. The days of liberalization and globalization are in and there is a spate of mergers and acquisition which is sweeping the corporate world. Consolidation in the banking sector should largely be synergy-driven to acquire a quantum jump in the performance of the combined entity $(2+2 \geq 5)$. It can be achieved by combining complementary strengths, giving a better geographical spread, serving a larger number of customers in a better way with more diversified products and skills, realizing the opportunities for cross-selling, containing the cost of the merged entity, reduced competition, better utilization of available resources and deriving economies of scale. Over the last one and a half decade, the banking sector in India has not only grown in terms of size but also matured, diversified and consolidated to contribute towards building a robust financial system. In this paper, five cases of bank merger have been taken and Null Hypothesis, i.e. there is no difference in mean value of selected variables before merger and after the merger, is set and found rejected (in most of the variables). On the basis of the overall analysis, merger of Bank of Karad Ltd. (BOK) with Bank of India (BOI) was more effective in most of the variables as compared to merger of the New Bank of India (NBI) with Punjab National Bank (PNB), Benaras State Bank Ltd. (BSB) with Bank of Baroda (BOB), Nedungadi Bank Ltd. (NBL) with Punjab National Bank (PNB) and Global Trust Bank Ltd. (GTB) with Oriental Bank of Commerce (OBC).

\section{KEYWORDS}

\section{Acquisition; Bank Merger; Consolidation}

\section{Backdrop}

A Merger or Acquisition ( $M$ \& A) is one of the most transformative undertakings in the life of a firm. Broadly, there are two ways to grow a business: organic and inorganic. In the organic path, a company achieves growth through expanding infrastructure activities and customer base and thus revenues and profits, whereas an inorganic process provides instantaneous growth, so M \& A can be considered as an inorganic strategy of growth. In the global environment, this strategy has become vital for achieving economies of scale, improving efficiency, reaching out to new markets and building new capabilities.

Over the last one and a half decade, the banking sector in India has not only grown in terms of size but also matured, diversified and consolidated to contribute towards building a robust financial system. Consolidation of banks through Mergers and Acquisitions is not a new phenomenon for the Indian banking system. It has been going on from the early days of modern banking through the setting up of English Agency House in the 18th century; the most significant merger was that of the three Presidency banks, founded in the 19th century, in 1935 to form the Imperial Bank of India (renamed as State Bank of India in 1955). Because of bank failures and amalgamations, the number of reporting commercial banks declined from 561 in 1951 to 89 in June, 1969. Merger of banks took place under the direction of the Reserve Bank of India during the 1960s. Indian Banking sector has been active in Mergers \& Acquisitions ever since Section 45 was incorporated in the Banking Companies Act in 1960. This section empowered the RBI to initiate the process of amalgamation of weak banks with strong ones, 
during 1961 to 1969; 36 weak banks, both in the public and private sectors were merged with other stronger banks.

There have been several bank amalgamations in India in the post-reform period. In all, there have been $37 \mathrm{M}$ \& A since the nationalization of 14 major banks in 1969. Of these mergers, 25 involved mergers of private sector banks with public sector banks. Prior to 1991, the amalgamations of banks were primarily triggered by the weak conditions of the banks being merged, whereas in the post-1991 period, there have also been mergers between private sector healthy banks, driven by the business and commercial considerations. However, merger of public sector healthy banks has not taken place till now. Objective of the Case Study: To evaluate the efficiency of mergers and acquisitions of the selected merged banks on the basis of selected variables prior to and after mergers and acquisitions [1-7].

\section{Research Design and Methodology}

\subsection{Sample Selection}

The present study concentrates on the M \& A in public sector banks. Public sector banks have been taken for the study because of the fact that the majority of the banking operations are undertaken by these banks, they are large in size and their area of operation is also very wide. The selection of $\mathrm{M} \& \mathrm{~A}$ cases has been made on the basis of availability and uniformity of data. These cases are as under (Table 1):

\subsection{Period of Study}

The mergers of the selected banks have taken place on different dates during the post reform period. In order to make a comparison of the performance of the merged banks, data for four years prior to the merger and data for four years after the merger have been analyzed. Thus, a period of nine years has been analyzed.

\subsection{Data Used}

The present study is based on secondary data published by the Reserve Bank of India, Annual Report of Public Sector Banks, Trend and Progress of Banking in India, Study Reports of various Committees set up by the Government of India etc.

\subsection{Selected Variables}

In order to judge the effectiveness of mergers and acquisitions of selected cases following 11 variables have been identified. These are

Capital: Capital represents the resources contributed by owners. The capital includes share capital and undistributed profits. The growth of capital indicates the capacity of banks to attract deposits, lend to the business unit and to borrow from the public. One of the aims of the merger is to increase the capital base of the banks. It is expected that the banks after the merger would have a sufficient capital base.

Deposits: The important element of conventional banking business is to accept deposits from the customers. One of the important sources of lending money is deposit. Without deposits the bank cannot provide the loan in different sectors. For the purpose the study the deposits refer to the bank balances in different accounts.

Investments: Investment refer to the investment of funds in the different areas such as government securities, subsidiary companies, mutual funds and others which are shown on the assets side of the balance sheet of banks. The main purpose of such investment is either to earn a return or/and to control another company. The investment helps to increase the total revenue and profit of the banking industry.

Advances: Advances are the other important aspect of conventional banking operations. In this study total advances include term advances, short term advances, advances to assisted company, advances to priority sector, advances in public sector etc.

Fixed Assets: Fixed assets represent the economic resources that are used to generate future earnings. Fixed assets refer to the net fixed assets. Without fixed assets it is impossible to run the banking industry. It is assumed that there would be a positive impact on the fixed assets

Table 1. Merged Banks.

\begin{tabular}{ccccc}
\hline S.No. & Name of Bank Merged & Merged/Amalgamated With & Date/year of Merger & Category $^{*}$ \\
\hline 1. & New Bank of India (NBI) & Punjab National Bank (PNB) & 04.09 .1993 & P-P \\
2. & Bank of Karad Ltd. (BOK) & Bank of India (BOI) & 20.07 .1994 & OP-P \\
3. & Benaras State Bank Ltd. (BSB) & Bank of Baroda (BOB) & 20.06 .2002 & OP-P \\
4. & Nedungadi Bank Ltd. (NBL) & Punjab National Bank (PNB) & 01.02 .2003 & OP-P \\
5. & Global Trust Bank Ltd. (GTB) & Oriental Bank of Commerce (OBC) & 14.08 .2004 & NP-P \\
\hline
\end{tabular}

*Category: P-Public Sector Bank; OP-Old Private Sector Bank; NP-New Private Sector Bank. 
after the merger.

Interest Earned: One of the main sources of income of the banking industry is the interest earned.

Total Income: The revenue earned from the different sources is total income. In the case of banking industry interest income is the main income. However, for the purpose of this study, total income refers to the interest received, dividend received, security transactions, exchange transaction, commission and brokerage etc. it is expected that the total income will be increased after the merger and acquisition.

Interest expenditure: Interest provided to customers in different saving and fixed deposit accounts and interest of debt capital is the interest expenditure. The interest expenditure can be minimized by increasing the operating efficiency. The operating efficiency can be increased by merger and acquisition.

Total Expenditure: The expense incurred to operate the bank is the total expenditure. The total expenditure should be controlled to increase the profitability. By increasing the operating efficiency the total expenditure can be reduced. It is possible by $\mathrm{M} \& \mathrm{~A}$.

Net Profit: The profit is an indicator of the efficiency with which the business operations are carried out by the corporate sector. The poor operational performance may result in poor sales leading to poor profits. The merger intends to boost profits through elimination of overlapping activities and to ensure savings through economies of scale. The amount of profit may be increased through reduction in overheads, optimum utilization of facilities, raising funds at lower cost and expansion of business.

Total Assets: Assets represent economic resources that are the valuable possessions owned by a firm. Assets are mainly used to generate earnings. The total assets refer to net fixed assets and current assets. One aim of business strategy namely, merger and acquisition is, the maximization of total assets of merged banks i.e., firms' ability to produce large volume of sales revenue. It is expected that the bank units after the merger would function efficiently.

\subsection{Analysis of Data}

The analysis has been made on the basis of the Mean, Standard Deviation, Growth Rate and " $\mathrm{t}$ " Test of different variables before and after the merger. In order to ensure the significance of change in the mean value before and after merger t-test has been used at the $5 \%$ level of significance and 8 degrees of freedom.

\subsection{Hypothesis}

The present work is essentially based on secondary sources; hence hypotheses are being tested by using published materials. For the purpose of study Null Hypothesis is that there is no difference in mean value of selected variables before merger and after the merger and Alternate Hypothesis is that there is a difference in mean value of selected variables before merger and after the merger.

\section{Results and Discussion}

(1) Changes of Capital of merged banks: Table 2 shows the mean value of capital before and after mergers and its variability, the growth rate of average capital before and after merger and " $t$ " values. The result presented in the Table shows that all the banks except Bank of Baroda and Oriental Bank of Commerce have upward growth of capital after merger; however, the growth rate of Bank of India is very higher than others. The result of "t" test revealed that Punjab National Bank-1993 and Bank of India have shown a significant change in the average capital after merger. The mean growth rate of capital clearly shows the fact that Bank of India achieved highest growth $(150 \%)$ followed by Punjab National Bank-1993 (104\%), Punjab National Bank-2003 (33\%), Oriental Bank of Commerce (-12\%). and Bank of Baroda $(-9 \%)$. The growth of the mean value of capital of Bank of Baroda and Oriental Bank of Commerce has found negative.

(2) Changes in Growth of Deposits of Merged Banks: Table 3 exhibits changes in average growth of

Table 2. Changes in Average Value of Capital and its Variability in Sample Merged Bank.

\begin{tabular}{|c|c|c|c|c|c|}
\hline \multirow{2}{*}{ S. No } & \multirow{2}{*}{ Name of the Bank } & \multicolumn{2}{|c|}{ Mean } & \multirow{2}{*}{ t Value } & \multirow{2}{*}{ Growth Rate } \\
\hline & & Before & After & & \\
\hline 1 & Punjab National Bank (1993) & $178.26(95.33)$ & $393.04(152.3)$ & 2.87 & $104 \%$ \\
\hline 2 & Punjab National Bank (2003) & $222.44(82.25)$ & $295.3(98.87)$ & $0.61^{*}$ & $33 \%$ \\
\hline 3 & Bank of Baroda (2002) & $356.06(142)$ & 322.78 (137) & $1.68^{*}$ & $-9 \%$ \\
\hline 4 & Oriental Bank of Commerce (2004) & $313.89(131)$ & $275.88(105)$ & $1.61^{*}$ & $-12 \%$ \\
\hline 5 & Bank of India (1994) & 389.21 (148.93) & $974.71(616.3)$ & 3.01 & $150 \%$ \\
\hline
\end{tabular}

@Figures in bracket are Standard Deviation. *insignificant. 
Banks: Table 3 exhibits changes in average growth of deposits and its variability of sample merged banks. It is clear that all merged banks have shown a significant growth of deposits during post-merger period than the average deposits received during pre-merger period. The application of t-test showed that all merged banks have shown a significant change in the average deposits after merger. The mean growth rate of deposits clearly shows the fact that Punjab National Bank-2003 achieved highest (96\%) followed by Oriental Bank of Commerce (70\%), Punjab National Bank-1993 (61\%), Bank of India (61\%) and Bank of Baroda (56\%), (Table 3).

(3) Changes in Growth of Investment of Merged Banks: Table 4 portrays changes in average growth of investments and its variability of sample merged banks. It is significant to note that all the merged banks taken for this study have shown a positive growth in investments during post-merger period compared to the investments made during pre merger period.

The application of $\mathrm{t}$ test showed that all merged banks have shown a significant change in the average investments after merger except Oriental Bank of Commerce. It is clearly understood from the mean growth rate of investment that Bank of India got a high rate (105\%) among sample banks. The low growth rate was achieved by Oriental Bank of Commerce (21\%).

(4) Changes in Growth of Advances of Merged Banks: Table 5 shows changes in average growth of

Table 3. Changes in Average Value of Deposits and its Variability in Sample Merged Bank.

\begin{tabular}{|c|c|c|c|c|c|}
\hline \multirow{2}{*}{ S. No } & \multirow{2}{*}{ Name of the Bank } & \multicolumn{2}{|c|}{ Mean } & \multirow{2}{*}{ t-Value } & \multirow{2}{*}{ Growth Rate } \\
\hline & & Before & After & & \\
\hline 1 & Punjab National Bank (1993) & 15526.85 (6902.61) & 25035.42 (3068.65) & 2.73 & $61 \%$ \\
\hline 2 & Punjab National Bank (2003) & 53618.37 (10285.87) & $105288.31(19004.54)$ & 3.98 & $96 \%$ \\
\hline 3 & Bank of Baroda (2002) & $48108.84(6850.15)$ & $75226.54(12658.26)$ & 3.83 & $56 \%$ \\
\hline 4 & Oriental Bank of Commerce (2004) & 33092.54 (5113.95) & $56394.11(1659.58)$ & 3.65 & $70 \%$ \\
\hline 5 & Bank of India (1994) & $17989.91(2779.03)$ & 28946.85 (4952.94) & 3.10 & $61 \%$ \\
\hline
\end{tabular}

@Figures in bracket are Standard Deviation.

Table 4. Changes in Average Value of Investments and its Variability in Sample Merged Bank.

\begin{tabular}{|c|c|c|c|c|c|}
\hline \multirow{2}{*}{ S. No } & \multirow{2}{*}{ Name of the Bank } & \multicolumn{2}{|c|}{ Mean } & \multirow{2}{*}{ t Value } & \multirow{2}{*}{ Growth Rate } \\
\hline & & Before & After & & \\
\hline 1 & Punjab National Bank (1993) & $6244.34(3175.18)$ & 11176.95 (1369.63) & 2.94 & $79 \%$ \\
\hline 2 & Punjab National Bank (2003) & 24067.01 (4166.93) & 42614.67 (6822.67) & 4.48 & $77 \%$ \\
\hline 3 & Bank of Baroda (2002) & $17385.36(3005.51)$ & $32849.03(5878.80)$ & 4.74 & $89 \%$ \\
\hline 4 & Oriental Bank of Commerce (2004) & $16138.12(1614.68)$ & $19566.11(1077.63)$ & $0.70^{*}$ & $21 \%$ \\
\hline 5 & Bank of India (1994) & 4826.48 (859.52) & 9915.19 (2008.67) & 3.82 & $105 \%$ \\
\hline
\end{tabular}

@Figures in bracket are Standard Deviation. *insignificant.

Table 5. Changes in Average Value of Advances and its Variability in Sample Merged Bank.

\begin{tabular}{|c|c|c|c|c|c|}
\hline \multirow{2}{*}{ S. No } & \multirow{2}{*}{ Name of the Bank } & \multicolumn{2}{|c|}{ Mean } & \multirow{2}{*}{ t Value } & \multirow{2}{*}{ Growth Rate } \\
\hline & & Before & After & & \\
\hline 1 & Punjab National Bank (1993) & $8066.42(1557.60)$ & $11847.21(1174.55)$ & 3.87 & $47 \%$ \\
\hline 2 & Punjab National Bank (2003) & $26768.64(6737.30)$ & $63817.87(15183.65)$ & 3.47 & $138 \%$ \\
\hline 3 & Bank of Baroda (2002) & $23405.64(3425.83)$ & $41584.79(10916.05)$ & 3.17 & $78 \%$ \\
\hline 4 & Oriental Bank of Commerce (2004) & $15964.13(3579.32)$ & 35901.05 (5853.43) & 3.55 & $125 \%$ \\
\hline 5 & Bank of India (1994) & $11399.01(1750.46)$ & $15816.60(3148.56)$ & 2.75 & $39 \%$ \\
\hline
\end{tabular}

@Figures in bracket are Standard Deviation. 
total advances and its variability in sample merged banks. It is clear that all sample-merged banks have shown upward growth in total advances after merger. As stated earlier, the t-test was used to test the significance of average change in total advances of the merged bank after merger. The application of $t$ test showed that all merged banks have shown a significant change in the average advances after merger. The analysis of growth rate (mean value) of total advances of sample banks clearly showed that Punjab National Bank-2003 achieved high rate of growth (138\%) followed by Oriental Bank of Commerce (125\%), Bank of Baroda (78\%), Punjab National Bank1993 (47\%) and Bank of India (39\%).

(5) Changes in Growth of Fixed Assets of Merged Banks: Table 6 shows changes in average fixed assets and its variability of sample merged banks. It is clear that Bank of India and Punjab National Bank-1993 have shown tremendous upward growth in fixed assets after merger. As stated earlier, the t-test was used to test the significance of average change in fixed assets of the merged bank after merger. The application of $t$ test showed that Punjab National Bank-1993 and Bank of India have shown a significant change in the average fixed assets after merger. The analysis of growth rate (mean value) of total assets of sample banks clearly showed that Bank of India achieved a high rate of growth (496\%), followed by Punjab National Bank-1993 (303\%),
Punjab National Bank-2003 (33\%), Bank of Baroda (29\%) and Oriental Bank of Commerce ( 17\%). The growth of the mean value of Fixed Assets of Oriental Bank of Commerce has been found negative.

(6) Changes in Growth of Interest Earned of Merged Banks: Table 7 shows changes in average interest income and its variability of sample merged banks. It is clear that all sample-merged banks have shown upward growth in interest income after merger.

As stated earlier, the t-test was used to test the significance of average change in Interest Earned of the merged bank after merger. The application of t-test showed that all merged banks have shown a significant change in the average interest earned after merger except Oriental Bank of Commerce and Bank of Baroda. The analysis of growth rate (mean value) of total assets of sample banks clearly showed that Punjab National Bank1993 achieved a high rate of growth (75\%), followed by Punjab National Bank-2003 (57\%), Bank of India (53\%), Oriental Bank of Commerce (30\%) and Bank of Baroda (25\%).

(7) Changes in Growth of Total Income of Merged Banks: Table 8 shows changes in average total income and its variability of sample merged banks. It is clear that all sample-merged banks have shown upward growth in total income after merger. As stated earlier, the t-test was used to test the significance of average change in total

Table 6. Changes in Average Value of Fixed Assets and its Variability in Sample Merged Bank.

\begin{tabular}{|c|c|c|c|c|c|}
\hline \multirow{2}{*}{ S. No } & \multirow{2}{*}{ Name of the Bank } & \multicolumn{2}{|c|}{ Mean } & \multirow{2}{*}{ t Value } & \multirow{2}{*}{ Growth Rate } \\
\hline & & Before & After & & \\
\hline 1 & Punjab National Bank (1993) & $100.13(40.75)$ & $403.48(10.92)$ & 5.60 & $303 \%$ \\
\hline 2 & Punjab National Bank (2003) & $719.49(69.30)$ & 957.97 (74.49) & $1.65^{*}$ & $33 \%$ \\
\hline 3 & Bank of Baroda (2002) & $618.76(27.31)$ & 797.23 100.84) & $1.40^{*}$ & $29 \%$ \\
\hline 4 & Oriental Bank of Commerce (2004) & $473.04(29.30)$ & $393.38(2.58)$ & $1.77^{*}$ & $-17 \%$ \\
\hline 5 & Bank of India (1994) & 83.99 (31.49) & 500.27 (169.22) & 3.62 & $496 \%$ \\
\hline
\end{tabular}

@Figures in bracket are Standard Deviation. *insignificant.

Table 7. Changes in Average Value of Interest Earned and its Variability in Sample Merged Bank.

\begin{tabular}{|c|c|c|c|c|c|}
\hline \multirow{2}{*}{ S. No } & \multirow{2}{*}{ Name of the Bank } & \multicolumn{2}{|c|}{ Mean } & \multirow{2}{*}{$\mathrm{t}$ Value } & \multirow{2}{*}{ Growth Rate } \\
\hline & & Before & After & & \\
\hline 1 & Punjab National Bank (1993) & $1604.41(494.98)$ & $2801.92(550.83)$ & 3.55 & $75 \%$ \\
\hline 2 & Punjab National Bank (2003) & $5691.54(947.47)$ & 8908.97 (932.06) & 3.97 & $57 \%$ \\
\hline 3 & Bank of Baroda (2002) & $5080.44(678.63)$ & $6346.33(455.28)$ & $1.36^{*}$ & $25 \%$ \\
\hline 4 & Oriental Bank of Commerce (2004) & $3589.91(288.82)$ & 4669.54 (386.79) & $0.93^{*}$ & $30 \%$ \\
\hline 5 & Bank of India (1994) & $1907.19(464.45)$ & $2921.35(628.71)$ & 2.39 & $53 \%$ \\
\hline
\end{tabular}

@Figures in bracket are Standard Deviation. *insignificant. 
income of the merged bank after merger. The application of $t$ test showed that all merged banks have shown a significant change in the average total income after merger except Oriental Bank of Commerce. The analysis of growth rate (mean value) of total income of sample banks clearly showed that Punjab National Bank-1993 achieved a high rate of growth (80\%), followed by Bank of India (59\%), Punjab National Bank-2003 (60\%), Bank of Baroda (34\%) and Oriental Bank of Commerce (27\%).

(8) Changes in Growth of Interest Expenditure of Merged Banks: Table 9 shows changes in average interest expenditure and its variability of sample merged banks. It is clear from the table that all sample merged banks have shown upward growth in interest expenditure after merger. As stated earlier, the t-test was used to test the significance of average change in interest expenditure of the merged bank after merger. The application of $t$ test showed that Punjab National Bank-1993 has shown a significant change in the average interest expenditure after merger.

The analysis of growth rate (mean value) of interest expenditure of sample banks clearly showed that Punjab National Bank-1993 achieved high rate of growth (66\%), followed by Bank of India (29\%), Punjab National Bank2003 (27\%), Oriental Bank of Commerce (21\%) and Bank of Baroda (11\%).

(9) Changes in Growth of Total Expenditure of Merged Banks: Table 10 shows changes in average

Table 8. Changes in Average Value of Total Income and its Variability in Sample Merged Bank.

\begin{tabular}{|c|c|c|c|c|c|}
\hline \multirow{2}{*}{ S. No } & \multirow{2}{*}{ Name of Bank } & \multicolumn{2}{|c|}{ Mean } & \multirow{2}{*}{ t Value } & \multirow{2}{*}{ Growth Rate } \\
\hline & & Before & After & & \\
\hline 1 & Punjab National Bank (1993) & $1721.12(547.86)$ & 3101.20 (665.62) & 3.55 & $80 \%$ \\
\hline 2 & Punjab National Bank (2003) & $6483.89(1144.06)$ & 10391.07 (874.79) & 4.65 & $60 \%$ \\
\hline 3 & Bank of Baroda (2002) & $5712.10(751.11)$ & 7642.07 (510.71) & 4.60 & $34 \%$ \\
\hline 4 & Oriental Bank of Commerce (2004) & $4170.34(428.49)$ & 5301.69 (420.73) & $1.37^{*}$ & $27 \%$ \\
\hline 5 & Bank of India (1994) & 2106.20 (548.69) & 3348.11 (741.07) & 2.38 & $59 \%$ \\
\hline
\end{tabular}

@Figures in bracket are Standard Deviation. ${ }^{*}$ insignificant.

Table 9. Changes in Average Value of Interest Expenditure and its Variability in Sample Merged Bank.

\begin{tabular}{|c|c|c|c|c|c|}
\hline \multirow{2}{*}{ S. No } & \multirow{2}{*}{ Name of the Bank } & \multicolumn{2}{|c|}{ Mean } & \multirow{2}{*}{ t Value } & \multirow{2}{*}{ Growth Rate } \\
\hline & & Before & After & & \\
\hline 1 & Punjab National Bank (1993) & 1152.59 (328.28) & $1918.05(348.88)$ & 3.25 & $66 \%$ \\
\hline 2 & Punjab National Bank (2003) & $3763.16(665.24)$ & $4781.66(322.04)$ & $1.92^{*}$ & $27 \%$ \\
\hline 3 & Bank of Baroda (2002) & $3427.03(429.31)$ & $3794.53(269.66)$ & $1.58^{*}$ & $11 \%$ \\
\hline 4 & Oriental Bank of Commerce (2004) & $2557.32(218.10)$ & $3094.17(329.51)$ & $1.08^{*}$ & $21 \%$ \\
\hline 5 & Bank of India (1994) & $1545.73(331.17)$ & $1996.42(367.15)$ & $1.65^{*}$ & $29 \%$ \\
\hline
\end{tabular}

@Figures in bracket are Standard Deviation. *insignificant.

Table 10. Changes in Average Value of Total Expenditure and its Variability in Sample Merged Bank.

\begin{tabular}{|c|c|c|c|c|c|}
\hline \multirow{2}{*}{ S. No } & \multirow{2}{*}{ Name of the Bank } & \multicolumn{2}{|c|}{ Mean } & \multirow{2}{*}{ t Value } & \multirow{2}{*}{ Growth Rate } \\
\hline & & Before & After & & \\
\hline 1 & Punjab National Bank (1993) & $1626.87(438.55)$ & $2762.15(463.28)$ & 3.82 & $70 \%$ \\
\hline 2 & Punjab National Bank (2003) & $5450.16(879.33)$ & 8303.81 (793.45) & 2.88 & $52 \%$ \\
\hline 3 & Bank of Baroda (2002) & $4753.34(655.17)$ & 5823.68 (476.53) & $1.85^{*}$ & $23 \%$ \\
\hline 4 & Oriental Bank of Commerce (2004) & 3231.98 (256.19) & 4192.25 (449.72) & $1.16^{*}$ & $30 \%$ \\
\hline 5 & Bank of India (1994) & $1986.88(405.76)$ & $2893.62(559.30)$ & 2.32 & $46 \%$ \\
\hline
\end{tabular}

@Figures in bracket are Standard Deviation. ${ }^{*}$ insignificant. 
total expenditure and its variability of sample merged banks.

It is clear that all sample merged banks have shown upward growth in total expenditure after merger. As stated earlier, the t-test was used to test the significance of average change in total expenditure of the merged bank after merger. The application of t test showed that all merged banks have shown a significant change in the average total expenditure after merger Oriental Bank of Commerce and Bank of Baroda. The analyis of growth rate (mean value) of total expenditure of sample banks clearly showed that Punjab National Bank-1993 achieved a high rate of growth (70\%), followed by Punjab National Bank-2003 (52\%), Bank of India (46\%), Oriental Bank of Commerce (30\%) and Bank of Baroda (23\%).

(10) Changes in Growth of Net Profit of Merged Banks: Table 11 illustrates changes in average net profit and its variability in selected merged banks. According to Table, the average net profit earned by merging banks taken for this study during post merger period was higher than the profit earned during pre merger period. The " $t$ " test clearly showed that the Bank of India, Oriental Bank of Commerce, Bank of Baroda, Punjab National Bank2003 have earned significant profits.

The analysis of growth rate of the mean value of total assets of sample banks clearly showed that Bank of India (580\%) achieved a high rate of growth, followed by
Punjab National Bank-2003 (188\%), Bank of Baroda (87\%), Oriental Bank of Commerce (86\%), and Punjab National Bank-1993 (23\%). The low growth rate was seen in the case of Punjab National Bank-1993.

(11) Changes in Growth of Total Assets of Merged Banks: Table 12 shows changes in average total assets and its variability of sample merged banks. It is clear that all sample-merged banks have shown upward growth in total assets after merger. As stated earlier, the t-test was used to test the significance of average change in total assets of the merged bank after merger. The application of $t$ test showed that all merged banks have shown a significant change in the average total assets after merger. The analysis of growth rate of the mean value of total assets of sample banks clearly showed that Punjab National Bank-2003 achieved a high rate of growth (105\%), followed by Oriental Bank of Commerce (74\%), Bank of India (62\%), Bank of Baroda (57\%) and Punjab National Bank-1993 (57\%).

\section{Conclusions}

A banking merger is just the same as the merger of two companies except that it involves banks. The important point in the bank merger is that banking activities of the participants will always be regulated. One of the routes adopted by the banks is that of consolidation. Mergers

Table 11. Changes in Average Value of Net Profit and its Variability in Sample Merged Bank.

\begin{tabular}{|c|c|c|c|c|c|}
\hline \multirow{2}{*}{ S. No } & \multirow{2}{*}{ Name of the Bank } & \multicolumn{2}{|c|}{ Mean } & \multirow{2}{*}{ t Value } & \multirow{2}{*}{ Growth Rate } \\
\hline & & Before & After & & \\
\hline 1 & Punjab National Bank (1993) & $43.07(32.49)$ & $52.86(124.72)$ & $1.02^{*}$ & $23 \%$ \\
\hline 2 & Punjab National Bank (2003) & $440.61(571.91)$ & $1267.97(281.41)$ & 3.23 & $188 \%$ \\
\hline 3 & Bank of Baroda (2002) & $404.88(413.51)$ & $757.96(158.25)$ & 4.33 & $87 \%$ \\
\hline 4 & Oriental Bank of Commerce (2004) & $303.88(295.60)$ & $564.53(119.50)$ & 2.34 & $86 \%$ \\
\hline 5 & Bank of India (1994) & -33.19 (19.29) & $159.30(171.92)$ & 4.21 & $580 \%$ \\
\hline
\end{tabular}

@Figures in bracket are Standard Deviation. *insignificant.

Table 12. Changes in Average Value of Total Assets and its Variability in Sample Merged Bank.

\begin{tabular}{|c|c|c|c|c|c|}
\hline \multirow{2}{*}{ S. No } & \multirow{2}{*}{ Name of the Bank } & \multicolumn{2}{|c|}{ Mean } & \multirow{2}{*}{ t-Value } & \multirow{2}{*}{ Growth Rate } \\
\hline & & Before & After & & \\
\hline 1 & Punjab National Bank (1993) & 18353.30 (3814.39) & 28873.15 (3176.14) & 4.39 & $57 \%$ \\
\hline 2 & Punjab National Bank (2003) & $60849.13(11639.23)$ & $124496.70(26020.00)$ & 3.80 & $105 \%$ \\
\hline 3 & Bank of Baroda (2002) & 55947.98 (7764.30) & 88098.72 (16761.09) & 3.51 & $57 \%$ \\
\hline 4 & Oriental Bank of Commerce (2004) & 37460.19 (7981.89) & $65171.34(3442.20)$ & 3.24 & $74 \%$ \\
\hline 5 & Bank of India (1994) & $20821.38(3008.20)$ & 33781.53 (5915.49) & 3.28 & $62 \%$ \\
\hline
\end{tabular}

@Figures in bracket are Standard Deviation. 
and acquisitions have been used to expand revenues and cut costs. In the above cases, Null Hypothesis, i.e. there is no difference in mean value of selected variables before merger and after the merger, is rejected (in most of the variables) in case of PNB \& NBI, BOI \& BOK, BOB \& BSB and PNB \& NBL, and Alternate Hypothesis, i.e. there is a difference in mean value of selected variables before merger and after the merger, is accepted. In case of OBC \& GTB, Null Hypothesis is accepted (in most of the variables) and Alternate Hypothesis is rejected.

On the basis of the overall analysis, merger of Bank of Karad Ltd. (BOK) with Bank of India (BOI) was more effective in most of the variables as compared to the merger of New Bank of India (NBI) with Punjab National Bank (PNB), Benaras State Bank Ltd. (BSB) with Bank of Baroda (BOB), Nedungadi Bank Ltd. (NBL) with Punjab National Bank (PNB) and Global Trust Bank Ltd. (GTB) with Oriental Bank of Commerce (OBC).

\section{REFERENCES}

[1] S. Agarwal, "Mergers and Acquisitions of Commercial
Banks in Indian Context,” IBA Bulletin, 2000, p.22

[2] American Bar Association, "Bank Mergers and Acquisitions: A Handbook Book,” 2007, p. 11.

[3] A. Banerjee, “An Insight: Merger in Indian Banks,” In: Mergers in the Banking Industry: A Global Perspective, ICFAI, Hyderabad, 2008, p. 134.

[4] Currency and Finance, RBI, 2008, p.15

[5] S. Mishra, "Bank Mergers: Is It the Right Solution?” In: Mergers in the Banking Industry: A Global Perspective, ICFAI, Hyderabad, 2006, p. 47.

[6] B. K. Tiwari, "Consolidation in Indian Banking Sector: Evidence and Challenges Ahead," Xlibris Publisher, Bloomington, 2013

[7] V. Gopala Krishna and Ch. Radhe Syam, "Legal Issues and Regulatory Perspectives in Indian Bank Consolidation,” In: Bank Mergers: The Indian Scenario, ICFAI, Hyderabad, 2007, p. 136. 